\title{
REGULATING CONVERGWNCE: Approaches of the EU and the UK, and New Issues in Media Regulation
}

Kerem Bater ${ }^{*}$

\begin{abstract}
Abstact
Traditomalfy Tele-communications and broadtasting originated from different resutatory cultures. In the past Tele-communications and Braddcasting markets within the EU were state-owned monopolies. In the 90 's the EU forced Member States to liberditze that Tele-commantcations markets. On the Brodcasting siate EU found it difficutit to develop at regutatory regime conceming content ant cutitut. Membar Stater had the sole power over these issues. But convergence between these stctors and information secholologits allow the EU to regulate this new area. This anticle will examine the development of convergence and its legal and regulatory inpitications.
\end{abstract}

\section{Introduction}

The dictionary definition of Convergence is the act of converging and especially moving toward union or uniformity'. According to Gibbons, there are three types of convergence: technological convergence, trans-frontier convergence and regulatory convergence. Techrological convergence may occur within an industry or different vpes of industrits regulated by different niles and regulatory bodies. The first type (intra-sector) may oceur mostly in the telecommunications sector. On the batis of technological developments, the difference between mobile networks and fixed networks was minimized. The second type (inter-sector) occurred in telecommuncations and media (i.t. broadeasting) sectors. The Information Technologies sector can also be added to these two. In this article, we deal with inter-sector convergence and the future of regulatory bodies in telecommunications and media sectors.

"Res. Assist. Mamara University European Conmunity Insiture. 


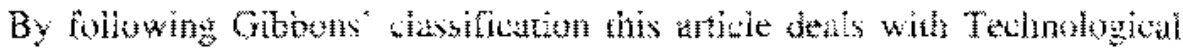
conversence and its implications for regulatory sace. As described below, convergence covers a huge area. And within the context of this article tnly a limited area of convergence is examined. Now Digita TV is a common form of convergene. Over a quarer of UK housebolds have digital TV. After examining the European and British appowach to convergence, the tegthation of Digital TV will be the pont to focus on.

\section{Description}

OFTEL ${ }^{3}$ in its second subnision th the Parliamontary Select Committe:

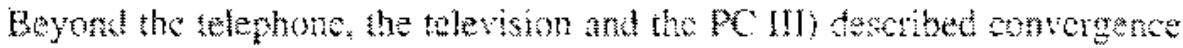
wa the coning logether of the following activites:

a. Telecommunications - vice and data sertices-

b. Computing - both hardware and sof ware.

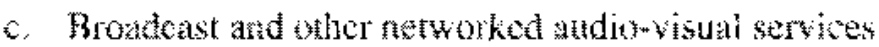

4. Any combintions of the abous (c.g interactive scrulces)

In the Commishion's Gresn paper the eximples of corverence are given as below:

- Hone banking and home-chopping over the Internet,

- Vorce over the Inemet;

- Emal, data and Word Wide Web acessis over mobie phone new works, and the use of wireless linkt to homes and businesses to conned them to the fixed ielecommunications networks;

-. Data service over dighal broudeasting platioms;

- On-he services combined whth telicision via systems such a Web-TV, as well as delivery via digial satellites and cable modems;

- Webcasting of news, sports, concers and of other audiwisual servires.

There are wo yrouss in the convergenca debate: "naximalists" helicke that conkergence will ocur in cyery area and there will be faster mowment

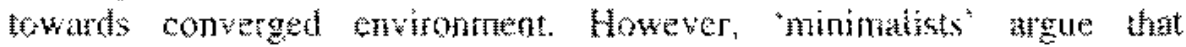
convergence will mol take place in th thot period of time and it will not weur ove: the wholc market. They give Digital TV an an example, Digital

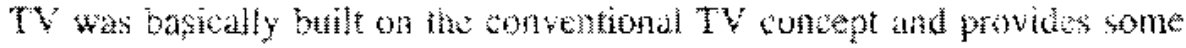
new converged servies. But ir is sill seen as $T V$. 


\section{Regulating Telecommunications and Media: The Differences}

The Telecommunications and Brondcasting sectots come from different regulatory traditions.

The Telecommunications Sector:

a. 'Carrier-regulated' with the obligation to ensure universal service

b. To provide non-discriminatory access and

c. Not to interfere with content.

The Media sector has been highly regulated with controls on the content of the broadcast.

In the Telecommunications Sector the flow of communication is

a. Irteractive and

b. One-to-one

In Broadcasting, the communication flow is traditionally

a. One"to-many and

b. Non-interactive

Telecommunications has nothing to do with content. This is because it comes from volce telephony, and in voice telephony the important rule is privacy. But the Broadcasting Media comes from radio and talevision and public influence is the main issue.

Almost every govemment has used broadcasting as a means to promote its deas and policies, In addition, taking into account the significant role that broadcasting plays in the functioning of a democratic society, there were measures to preserve plutalism and a balanced range of choices/programmes so as to cater for different groups/ audiences (e.g. minors, minorities, etc. as well as to promote national heritage, cultural diversity and different hewpoints.

The focus of the regulatory framewer for the felecommunications sector has been on networks and service provisions but not on the content regutation carried over those networks.

In telecommunications services all users are treated allke in temis of prices and provision of service quality. But in the broddcasting sector all users are 
not treated atike. Conten regulation takes account of the different needs expressed by the audience: children. cultural minoritice, religious beliefs atc. Media regulation is more complicated compared to telecommunications becalise it has cuitural, social and political concems and these concerns change from community to conmunity and from state-termstate. But telecommuication mues are universal and they are applicable to an states.

\section{The problems of EL regulation of Convergence}

1. The industrat sectors that are subied to convergence start from very different leveis and methods of regufation. The telecommunications sector to librralised but not unifondy 30 , supervised by independent national regulators, with a comprehensive EL law franework, and subject to general antitrust review. The breadsasting sector remains hosily zegulated natonally, with minimat EU rules in place, and without randatony arm's

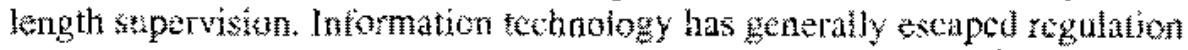

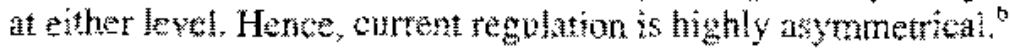

Commiszon tirectives have proved very imporiant in promoting Liberalization. Article $90(3)$ of the Treaty entites the Commissisn to iszue directives of decistom directly to member states in onder to ensure the application of compctition rules provide in the Treaty to undertakings (be they private or public) with special of exclusive rights. Since this proviston indudes pubic telecontmanteations aperarors (PTOS), the Commission has been able to use it to bypass the voling of directives by the Countil of Ministers. On that basis, a number of directives were isuced by the Commission for the lberalization of slecommunications terminal equipment, services, sateliste communications, cable television networks, mobile and porsonat communications and for full competition.

Menber states want la regulate the brondcating sector with dornextec legistation. One of the very fex instances of ED legistation in the hroadcating sector is "The Television Without Fronters" directive. In the legislative process the German delegation insisted on the Comol ataching a witten statement wo the Directive describing the prewsion as "wolitically" rather than 'iegolly' binding. This change made the Directive open to interpretation and, furthermors, cffectively prevented the Conmission from bringing Momber States to coutr for falling to reach quota goals, and thus brexkhing the Directive.

2. From an instimilonat penperive, the tuat protoms of the requisite sope and level of regutation pronent thertselves with particular urgericy in this 
area, where market developments regularly outpace attempts at regulatory reform.

3. These problems are chmpounded by the lack of a coherent legal framework within which they can be atdressed, other than general principles of EU law.

Unlike the convergence between technologies, convergence through EU Law is not mainly a horizontal proeess; it has an important vertical, or hierarchical, dimension. It is predicated upon the supremacy of Europeran law toward the legal norns established at a higher systematic level. Inversely, sach convergence takes place through the implementation at national level of EU norms elaborated by way of hamonisation.

\section{The Green Paper on Convergence}

The Convergence Green Paper is based on three fundamental premises:

a. That a technolggy and market driven process of convergence is occurring;

b. That this process is of pre-eminent potential signifeance to job crextion, gowth, regional and global economic integration, as well as ovetall European competitiveness,

c. That obtaining the tequisite regulatory mix to promote the convergence process is key to maximising the desired benefits thereof.

In taking these reflections further and building on the areas identified above. the Commission believes it would be useful to deepen the debate on three key issues ${ }^{\text {" }}$, namely:

1. Access to networks and digital gateways in a converging en vironment

2. Creating the framework for investment, innowation, and encouraging European content production, distribution and avalability, and

3. Ensuring a balanced approach to regulation

These are thres of the key themes ratsed in the oral and written comments. 


\section{What to Regulate}

The developneat of multi-channel service protision and the anticipated ase of digital technology have essentally remoted the spestrm barriet to entry. As the UK Green Paper on Convergence ${ }^{\text {"." }}$ states "the presumpition that broaleating and communications should be regulated shoud thesefore in general be reversed." So, negative content regulation bocmes more important than positive content regulation and new istus, apan from content regulation, gain more frmpotance.

There are three isstes raiscd in the concept of regulating Dightal TV:

a. Conditional Arous systems $(C A)$

b. Parental Contrel Systoms

c. Flcotronic Putran Gude (EPG)

Apart from these categories ownership limits and coss-media ownership subjocts are also discusced among writcrs but they are common issuts of media and browdeasting sectors and not specific isstes, for convergence. Here only the ssues raised foum convergence are exanined.

\section{a. Conditional Aceess Systems:}

Access systems the been used for two decades. They were used in analogue tahnology as well as atgital. But the significant difterance betwen the two is the expansion of substiption brodusting services and interactive services.

The apcrator of thes $\mathrm{CA}$ systems are commonly referred to as "gatekeepers". Recause they control the viewers" aceess to services. In othet words, only vewers wha have the suitable equipment for reception and pay for it wan access the services supplied by these operators.

There is a common digital broadcasting standard within the EU (DVB) but therc is no conditional access standart. The European Commission's

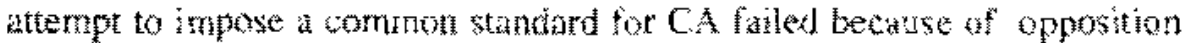
from broddcasters dominan in the existing andagte pay-TV matet. The existing broddasters ave already developed their own $C$ systems and made investments.

Upon this falture. the Europeran Commission tevelopen another appronct that is callod 'riulterypt". There will be a common interface on the sot-top"

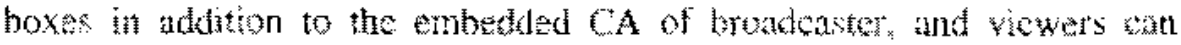
purchase a card fsimitar to PCMCIA sards used in laptops and wath wher subseription services. 
On the one hand, the EU tried to launch the multicrypt system as a EU standard, on the other hand it regulated the existing operators of digital platforms. Dircetive 95/47 on the Use of Standards for the Transmission of Television Signals stated that;

Member states shall take all necessary measures to ensure that the aperators of conditional access services, irrespective of the means of mansmission

- offer ta all broadcasters, an a fair, reasonable and nondiscriminatory basis, technical services enabling the broadcasters" digitally-transmited services to be recoived by viewers authorited by means of dechders administrated by the service aperators, and comply with Communty competition law, in particular if a dominant position appears.

-keep separate financial accounts regarding their activity as otanditional access providers.

Within this perspective, OFTEL published a document on the Pricing of Conditional Access Services for Digital Television in October $1997^{\text {14 }}$, According to this documient:

2.3. The equipment most viewers homes will only give access to pay television services using the particular conditional access system incorporatal in to the setwtop-bor. Conditional access system $B$ is therefore nat a substitute for condivional acesss system A. Since set-top-boxes will, at least intitally, be relatively expensive' there are likely to be significant switching costs for housetolds whing to change to a different conditional access system requiring the use of a difizent set top-box.

2.4. Content providers are llakely in turn to use the system giving actess to the greatest number of subscribers. The pasition is therefore likely to be one which is sulf-reinforcing antal which rival systems are likely to find difficult to break.

Apart from these sector specific regulations, competition law is another way to regulate CAs. By the $90 \mathrm{~s}$, "essential facilties doctrine" had been the subject of attention. It started with Commission"s decision in Sealinkt B k Holyhead ${ }^{15}$ in 1992. The expression "essential facility" was used in situations where an undartaking seeks access to a physical infrastructure such as a port, airport or pipeline and, case law add ohere situations like to 


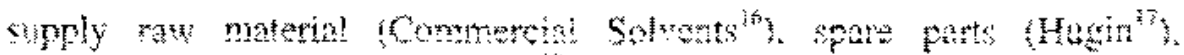
intelectual pronerty tohts (Magin! ${ }^{13}$. According to Whish, in the context of Article 82 , the exsential factities dectrine is a nutural consequence of the judgersen in Cotrmercin solvents, that a retusal to supply a customer in a down strem market wond anomt to at abus if the effect would be to

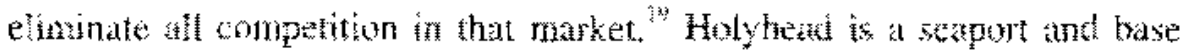
for fortes navigating from LK to Irelatd. After privatsation Hotyead was

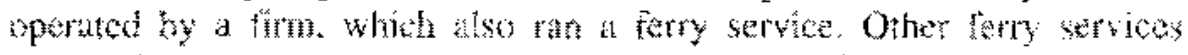

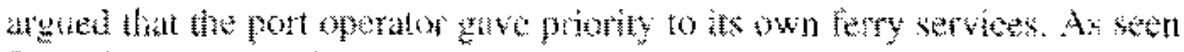
frem the context this case is very stmilar to sieutame in CA. Genealiy CA

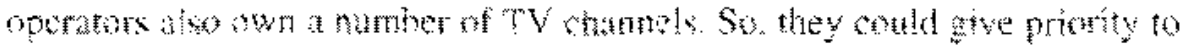

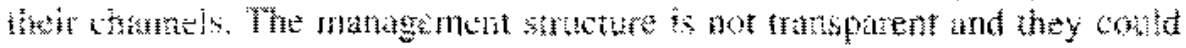

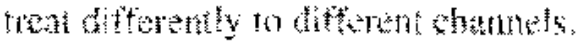

The man point in the estential acitites doctrine is the nature of the

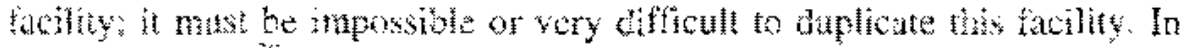

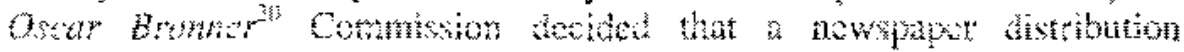
network (home dellvery) is not an essental facility, betuse there are several other ways for rowpaper deltyery, and it is not impossible to extablist andher bone dolverg yysem.

Here, in ligital TV, set-topboxes with smulcrypt ooding systems conld form an essential factity. It is very ditficult to diphicate the service exth

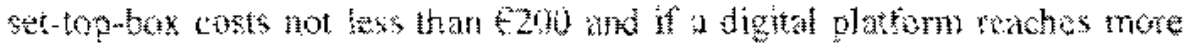
than five millon hones, as in the case of $5 k y$ tigital, it is neary impossble to duflicate this service.

\section{b. Parental Control Systems}

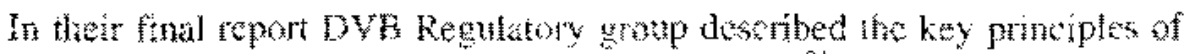

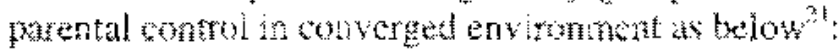

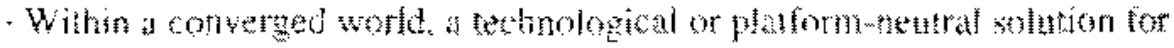
horizontally wnifed regulatory treatment of content can provide greater consigtency, both for content fatkagers and connmers.

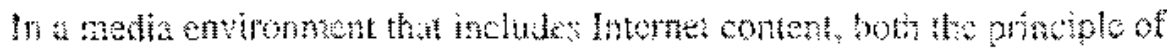

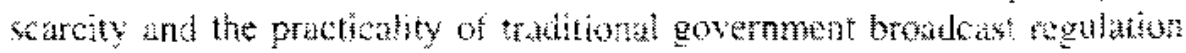
maty be diminished.

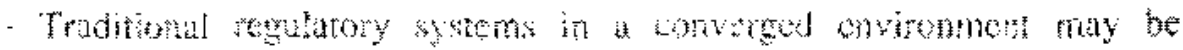

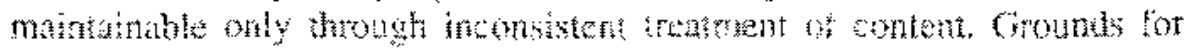

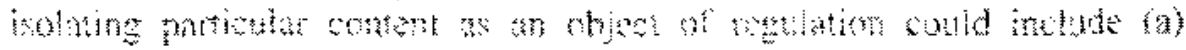


technological means of delvery, (b) domestic origin of content, and(c) size of audience. All of these would raise practical, policy, and atministrative difficulties.

- As volume of content increases, viewers may increasingly rely on metainformation about content and filtering or navigating methods for sorting metainformation, both for poxitive selection of desired material and blocking of offensive material. Markets in metainformation may play a central role in a converged environment. Parents, governments, or content packagers, however, may prefer that access to metainformation for parental control not be market-idependant.

- Avallability of rating and filtering systems may make self-regulation for parental control purposes an increasingly viable option in the converged media environment.

Parental controf systems are mostly related with content regulation. Before the digital revolution the spectrum was too narrow lo broadcast thematic channels and regulators tried to keep the balance. With Digital TV in becomes easistr to latnch hundreds of channels, so adult and violent contents are commonly broadoasted in digital platforms.

One of the main goals of European content regulation is "restricting children from access to adult content'. In ordet to reach this goal filter tools and EPGs can be used in the following two ways:

a. Traditional way of protection is parental lock on "TV sets. The channel showing adult materials can be locked and the child is not able to watch them.

b. Filtering Tools: traditional parental lock is only locks the channels but nothing to do with ordinary channels showing adult material in their schedule. In 1996 the $V$-chip was mandated by US govemment. TV sets having screens bigger than 13 inches installed with $V$-hip. The content is rnarked and the $V$-chip controls, if there is programming of adult material the TV set does not show it. This technology is for antogue TV sets but it can be easily transferred to digtital. 


\section{c. Electronic Program Guide}

EPG wan be listed under CA but it is incrassing th powers and therefore nesds to be exammed separately. EOP is a new kind of teletsext, but it is more than teletext. According to ITC codte of conduct ${ }^{23} \mathrm{EPG}$ Service' is an information serviee, which tan indude visual inages, retang to the promotion, listing or selection of television programusts or services, or other servises where more than me service is avallable iparas. The constmer is able to wavgate betwen serves whout reference to the

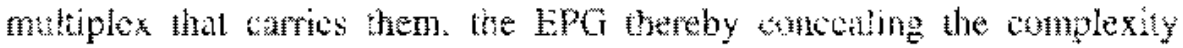
from the viewer. Wint EPG one can easily reach program listings and detafled information. and mark the program he wants wo wateh, So, EPG is

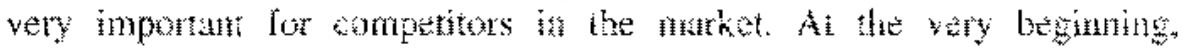
plation operaturs only put their own chanels to the fistings.

Font a regulatory perspective control of the EPG is mpontant as it presides a daty opporwnity io intuene viewing shares. The navigation technology provides for stratengan control of the digital TV industry. as they are the first Servise that confrorts the viewer and they inform the consuner of the services that are aviliable. The EPO will be the de fasto method by which

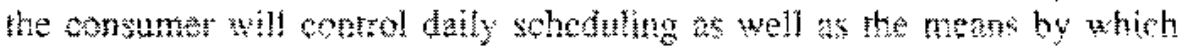
service providers will matat their content to consumers. As the andience becomes increasingly agmented across multiple chamels the navigation wattwae will become the crucinl tool for infucncing viewing pattents.

The potential for abuse is obvious given the purpose of the EPC. Consmer selection of programming services my be influenced by the navigation solware, and any bias in the lising will have serous impliontions for contert pzoviders.

Oite $^{\text {2t }}$ has taken $a$ very broad definitional view of conditional acess services; it has claimed the disputed right to regulate all Elos that are marrict to a conditional acoes system, taking the view that the EPC is an integrat element of the conditonats access system. Although tot specifie on the atetails Oftel will, by equatation, seek to prevent any restiction of competition beween broadcusters on the EPG.

The EPG povides an example of a regulatury istue whore argubbly the

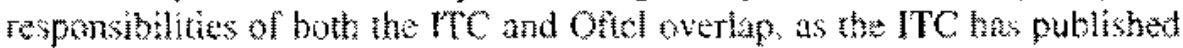
a Code of Condue tor the provisan of $\mathrm{mpl}$ systems. White the Code is

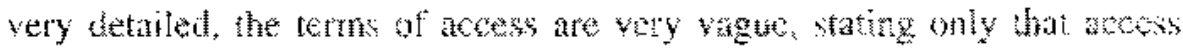
must be provided on fair, restonabie and nim-discriminatory torms. 


\section{How to Regulate: De-regulation, Re-regulation, Self-regalation}

If you onsider the media products as purely commercial and without political and social significance then regulation will no longer be necessary in the middle and the long term. Nowadays it is true that broadcasters primarily deal with entertainment but they also have potential of "mediation', They are windews of our houses that are open to the world. We watch their choices. Therelore, there is a pubice interest and need for regulation.

With news forms of media the main issue is not de-regulation but reregulation. of course media owners argue for te-regulation but it does not serve public interest. The need for existing regulatory bodies in order to fit the new values of converged age forced governments to change.

Do convergent media needs convergent regulation?

The response of the UK to this question is OFCOM, In the Telecommunications White Raper ${ }^{27}$ the reasons were given as below

82.1 The current framework for regulation of communtcations in the UR is complex. Technology has also moved faster than regulation can keep up. As convergence continues to accelerate, such complexity ant potertial for confusion will only increase unless regulation is reformed

8.2.2. We theriore need a simpler and more flexible system. It will be estential for the regutator to have delecated powers to act independenty in response to fast-changing circumsiances. The system should also recognis that content and networks, in econtwic tarms, are beconting more and more intertwined. Networks are often worthess without content. bul, in the early stages of network development, a compony can't sell content unless it can butd out its own network or get actess to someone else's.

There is also a debate between sector specific regutation and competition law. Competition rules are applied in convergence as well. It is true that the sector-independent character of competition law makes it a llexible horizontal tool setting the broader regulatory fomewak. Nevertheless, as inferred from the analysis above, the fulfilment of explicit objectives, especially public interest aims, requires concrete regulation. Such specitic regulatory measures tan safeguard public interest abjectives while at the 


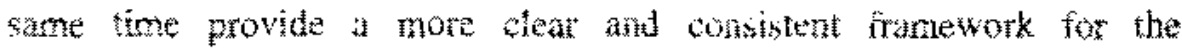
application of compention rales.

\section{Conclusion}

According to Oftel's latest research ${ }^{28} 11$ million UK homes -45 装 - are connected to the Internt. However, aimst all of these houses art connected via sarrow band dial up access. Narrowband access does not allow uscrs watching video as they to with TV sets. Another Oftel research work an Digital TV ${ }^{29}$ (published in September 2001) shows that people think ditital TV mears more channels and more choice. They tarely use interive services only a few of them have uxed e-mail via set top box. Although the regulators attach excessive inportane to the EPG, people take 'the list' as a coninuous one, rather that a hiorarical on . However, thannel identity and branding have becont crucial, given the few seronds (maximum) whith viewers will give a channel to "prove" itself of interest.

The Cultute, Media and Spow Conmitte of the UK House of Commons, in its Fourth Report on the Multinedia Reviution suggested that the Internet would become increasingly a platforn for apdio-visual content barely distinguistable from boads asting content. This does not mean that it can be subject to regulation comparable to hraadcasting (para. 114).

A further point of sone importance is that there is no single new media form or mutket, and it is likely that such uniform markets will remain distinet from each other; for instance, there is still a clear distinction between television-type services and on line services. Techrologic convergence may be imminent in the form of television intemet aceess for Web TV) becoming cheaply available, but the cultures remain radically differem. ${ }^{30}$

As mentioned before the diflerence in regulatory traditions of internet and broatcasting influcnced the regulation efforts of convergence." The mathet is getting bigger and players are also growing very rapidiy. Players want the market yegulated by comperition rules. The general competition provisions of the EU Treary alone are not adequate to dealing wht the shalienges of convergeace.

The restrictions on ownerwip should be removed. Convergence and digital TV need more invertment than analogie brotdo asting does. Supplying set top-boxes, more satellite transponders, sofwiare, CA systems mean more investment and these investments can oniy be made by cross" subsidisation". For digital plat forme, monopolization of manket is not such a harmf al developmont. The important point is regulating the digital platform 
and letting it open to all competitors in the broadcasting market. It should be noted that in some EU countries such as Greece single digital platform is antictpated. In order to prevent misuse sources having single platform shall be preferable. The UK should follow the same approach and let Sky TV dominate the maket. But on the other hand all free-to-air channels and other subscription channels must take place on the $\$ k y$ platform (from the end of 2001 most of them already on sky digital) and conditions supplied must be adequale to all competitors.

It appears that regulating convergence by the EU will not create a Europe. wide regulatory body. The EU will prepare some guidelines for members when necessary and national regulators will be in chatge in the foreseeable future. Regulating media is still a national issue and it is very difficult for convergence to change this situation. With slight changes, conventional TV still remains as the best choice for most houses. Regulation in ordinary broadcasting will be needed for a long tine In the muti-channel world content regulators should smoothen the rules and let people self-regulate themselves.

\section{Endnotes}

${ }^{1}$ Merriam-Webster Online Dictionary, thupllww webster conto

${ }^{2}$ Thomas Gibhons, Regulating the Media, Sweet Maxwell, London-1998, pp.14 18

${ }^{3}$ Cuture, Media And Spont Committe Inouiry Into Audio Visual Communications And The Regulation Of Brozdcasting "Beyond The Tetenhone, The Television And The $\mathrm{Fe}-\mathrm{II} \mathrm{I}^{3}$ chtp:/7wtwoftel _rov.lak/publications/1995_98/broadcasting/dems398.htm

4. Cincera, "The Eutopean Union chatent regulation in the converged commuthication enviroment", in European Telectmminications Liberalisation, ed. Kjell A, Eliassen and Marit Sjovarav, Routledge, London-1990, pp.85-86.

" M. Michalis, "Eurogean Union Brondcasting and Thecoms Towards a Convergent Regulatary Regime?" European Journal of Communication, SAGE 


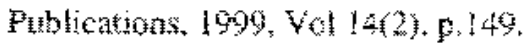

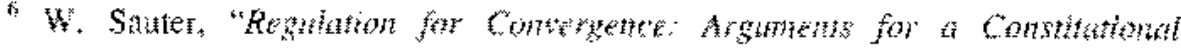

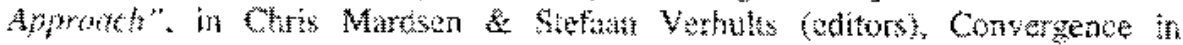

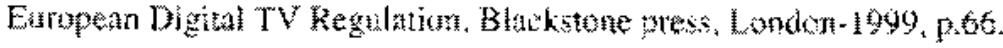

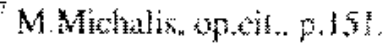

P. Cinceria spit. p.7\%

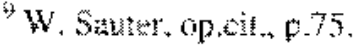

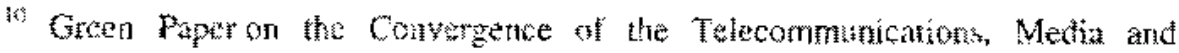

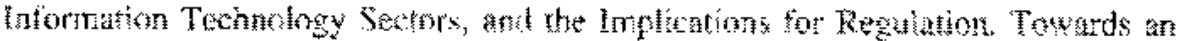

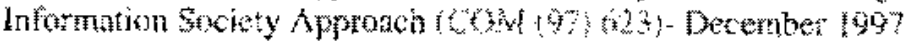

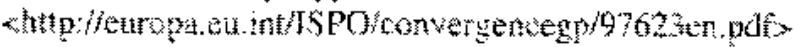

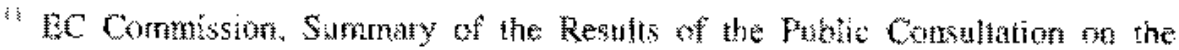

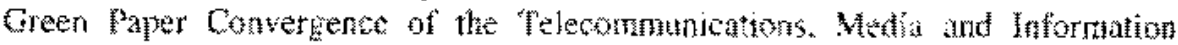

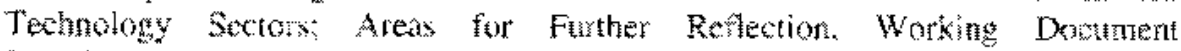
[Set $(98) \mid 284]$

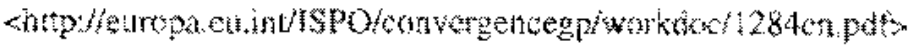

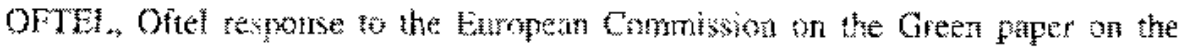

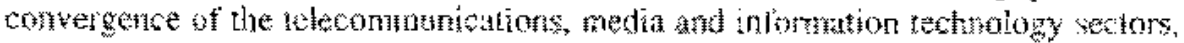

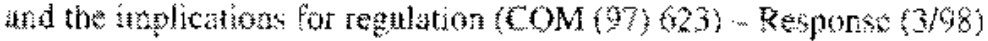

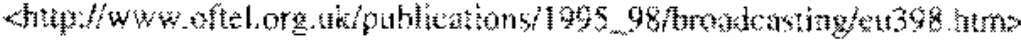

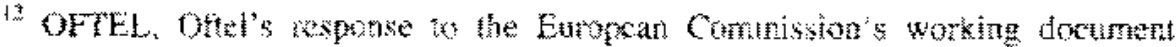

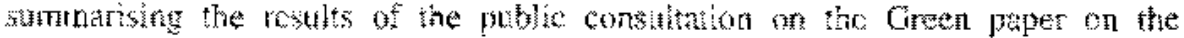

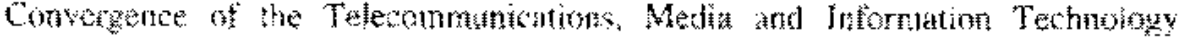
sctors.

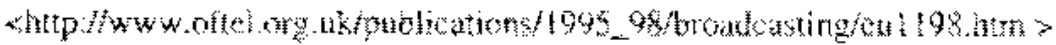

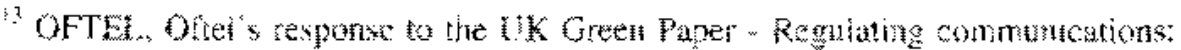

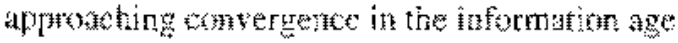

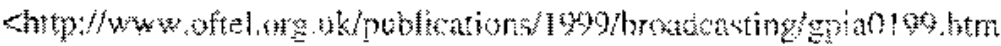

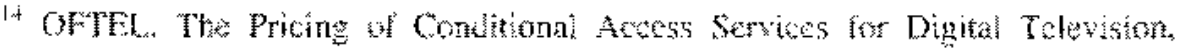
Consultative Document, Ochoer-1993 


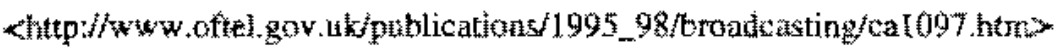

Seatik / $\mathrm{B}$ and - Holynead: interim measures, f1992) 5 CMLR 255.

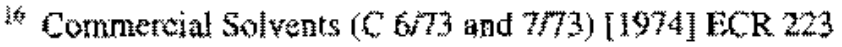

${ }^{1 *}$ Hugen $v$ Comunistion $\left(\mathrm{C}_{2} 278\right)$ [1978] ECK 1513

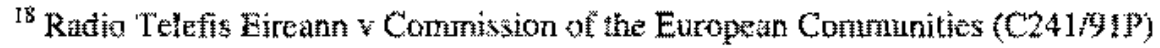
[1995] C.ML.R. 718 (EC)

${ }^{18}$ R Whish, Competitun I.

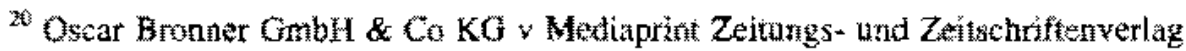
GmbH \& Co KG (C797) 1999] 4CM.LR, 112 (ECI), [1998j ECR 1-7791.

21 DVB Regulatory Group, "Parental Control in a Converged Commuicatons Eavironment: ${ }^{\prime}$ October $2000,0.7$.

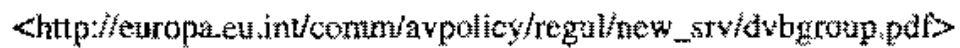

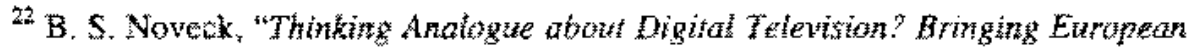
Contartinto the information Age", in Chris Mardsen ${ }^{4}$ Stefan Verhults (editors),

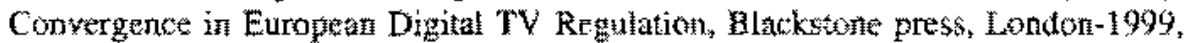
$p_{*} \times 0$

Z3 Indepentent Television Comnission, ITC Code of Conduct on Electronte Programme Gúdes, June 1997.

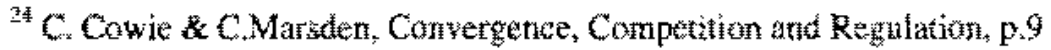

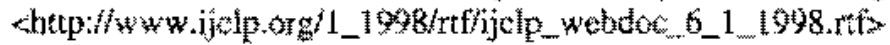

${ }^{25}$ OFTEL, The Regulation of Conditiona Access for Digital "elevision Servicus: OHEL Gutdelines

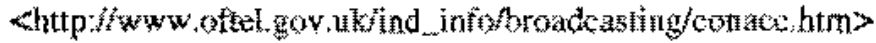




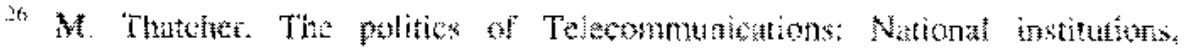

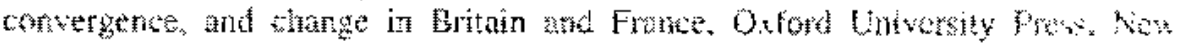

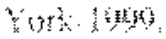

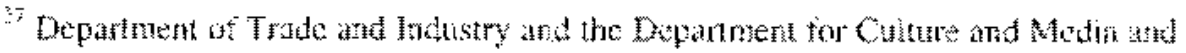
Spont, Consnumications Whita Paper

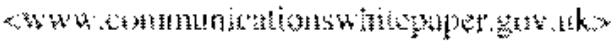

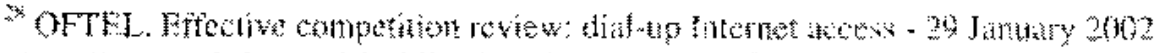

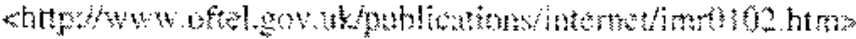

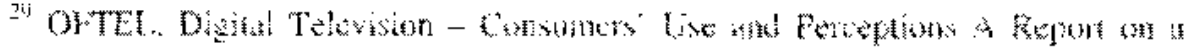

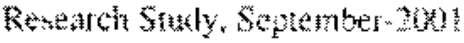

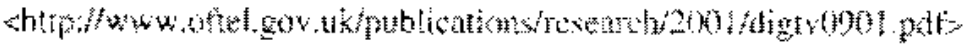

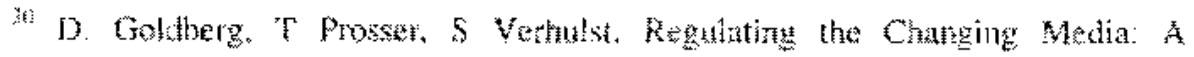

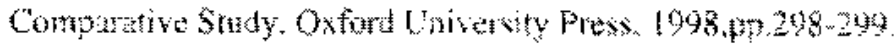

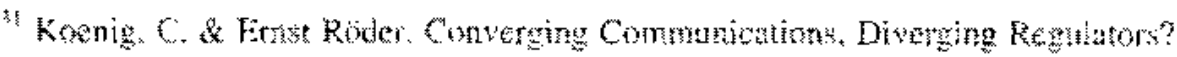

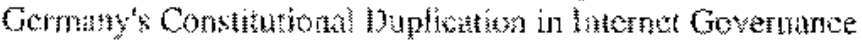

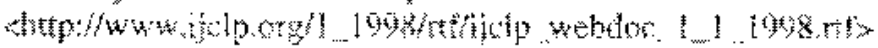

